\title{
BBS9 wt Allele
}

National Cancer Institute

\section{Source}

National Cancer Institute. BBS9 wt Allele. NCI Thesaurus. Code C114661.

Human BBS9 wild-type allele is located in the vicinity of 7p14 and is approximately $477 \mathrm{~kb}$ in length. This allele, which encodes protein PTHB1, is involved in ciliogenesis. Mutation of both copies of this gene is associated with Bardet-Biedl syndrome 9. 